\title{
Abnormalities in Hepatic Enzyme Activities during Development of Diabetes in Db Mice
}

\author{
A.Y. Chang and D.I. SchNeIDER
}

Diabetes Research, The Upjohn Company, Kalamazoo, Michigan, USA

Summary. Seven hepatic enzymes were assayed in vitro in diabetic and control $\mathrm{C} 57 \mathrm{BL} / \mathrm{Ks}$ mice at 1,2 , and $4 \frac{1}{2}$ month. An elevation in phosphoenolpyruvate carboxykinase and glucose-6-phosphatase was observed before the onset of hyperglycemia in $\mathrm{db}$ mice at the age of 1 month. At two months, these mice had hyperglycemia, hyperinsulinemia and high levels of phosphoenolpyruvate carboxykinase, glucose-6-phosphatase, fructose-1,6diphosphatase, pyruvate kinase and 6-phosphogluconate dehydrogenase. The $41 / 2$ month old db mice had normal plasma insulin, severe hyperglycemia, exorbitant amount of hepatic gluconeogenic enzymes and reduced quantity of glycolytic and pentose-phosphate shunt enzymes. The disturbance in enzyme activities and blood sugar was partially controlled by placing the animals on a limited diet beginning at the age of 1 month. In vivo studies indicated that hyperglycemia resulted, at least in part, from an accelerated rate of gluconeogenesis. The development of diabetes in these mice is discussed with reference to these findings.

Anomalies d'activitès enzymatiques hépatíques pendant le développement du diabète chez la souris db

Résumé. 7 enzymes hépatiques ont été étudiés in vitro chez les souris diabétiques et contrôles de la souche C57BL/Ks, à l'âge de 1, 2, et 4 mois et demi. Avant l'apparition de l'hyperglycémie, une augmentation de la phosphoénolpyruvate carboxykinase et de la glucose-6phosphatase a été observée chez la souris $d b$ agée d'un mois. A l'âge de 2 mois, ces souris présentaient une hyperglycémie, une hyperinsulinémie et une activité accrue de la phosphoénolpyruvate carboxykinase, de la glucose-6phosphatase, de la fructose-1,6-diphosphatase, de la pyruvate kinase et de la 6-phosphogluconate déhydro. génase. Chez les souris $d b$ de 4 mois et demi, on a observé des taux normaux d'insulinémie, une hyperglycémie sévère, une activité extrêmement élevée des enzymes de la gluconéogénèse hépatique et extrêmement réduite de ceux de la glycolyse et du cycle des pentoses. Les désordres de ces enzymes ainsi que ceux du glucose sanguin ont pu être contrôles partielleuent en soumettant les animaux à une restriction alimentaire dès l'âge d'un mois. Des études in vivo ont indiqué que l'hyperglycémie résulte, en partie du moins, d'une gluconéo. génèse accélérée. L'apparition du diabète chez la souris est discutée à la lumière de ces résultats.

Veränderungen von Enzym-Aktivitäten der Leber während der Entwicklung des Diabetes der dbdb Maus

Zusammenfassung. Die Bestimmung der Aktivität von 7 Enzymen der glykolytischen und gluconeogenetischen Ketten in Leberextrakten von 1, 2 und 41/2 Monate alten $d b / d b$ Mäusen und normalen Kontrolltieren ergab folgende Resultate: Bei noch normoglykämischen $d b / d b$ Mäusen im Alter von 1 Monat waren PhosphoenolpyruvatCarboxikinase und Glucose-6-Phosphatase-Aktivität erhöht. Im Alter von 2 Monaten (manifeste Hyperglykämie und Hyperinsulinämie) waren außer den Schlüsselenzymen der Gluconeogenese auch die Aktivitäten der Pyruvat Kinase und der 6-Phosphogluconat-Dehydrogenase erhöht. Bei $4 \frac{1}{2}$ Monate alten $d b / d b$ Mäusen (schwere Hyperglykämie, zur Norm abgesunkene Plasmainsulinkonzentrationen) waren die Aktivitäten der Schlüsselenzyme der Gluconeogenese stark erhöht und diejenigen der Enzyme der Glykolyse und des Pentose-Shunts erniedrigt. Einschränkung der Nahrungsaufnahme einen Monat nach Geburt verhinderte das Auftreten dieser Veränderungen nur teilweise. Auf Grund von in vivo Experimenten wird. angenommen, daß die Hyperglykämie, zumindestens teilweise, auf verstärkte Gluconeogenese zurückzuführen ist.

Key-words: Spontaneous diabetes, diabetes in mice, mutation: diabetes, liver enzymes, gluconeogenesis, diet and diabetes.
The mutant strain $d b / d b$ of $\mathrm{C} 57 \mathrm{BL} / \mathrm{Ks}$ mouse develops diabetic syndromes resembling those found in man [3]. Its diabetic symptoms appear to manifest in two stages. The early period is characterized by excessive plasma insulin, reduction in $\beta$-cell granules, increase in glucose oxidation and elevated level of gluconeogenic and lipogenic enzymes, whereas in the later stage, there is a normal plasma insulin level, retarded glucose oxidation, and high gluconeogenic enzyme activity [3]. The symptomatic changes during the development of diabetes signify certain causative biochemical derangements in the $d b$ mouse. This paper describes some studies on disturbances in hepatic enzyme activity that accompany the manifestation of diabetes in these mice. Furthermore, data obtained from studies on the rate of gluconeogenesis in vivo are also reported.

\section{Materials and Methods}

Diabetic ( $d b / d b)$ and control $(+/+)$ C $57 \mathrm{BL} / \mathrm{Ks}$ mice were purchased from the Jackson Laboratory.
A majority of the animals were allowed food and water ad libitum. Three pairs of mice were placed on a limited diet starting at the age of 1 month, and every day 2.25 g Purina Mouse Chow was given in the afternoon. The diabetic mice usually consumed their food within a short interval, whereas the ration lasted $24 \mathrm{~h}$ for the control mice. Animals used in gluconeogenesis studies were fasted for $16 \mathrm{~h}$. All studies were initiated early in the morning.

Other materials and methods, e.g. determination of plasma insulin, blood glucose, liver proteins, enzyme activities, and rate of gluconeogenesis, were as described previously [2].

\section{Results}

During the development of diabetes, the livers of $d b$ mice increased in size from $6 \%$ to $8 \%$ of total body weight between 1 to 2 months of age (Fig. 1). Liver hypertrophy was somewhat attenuated in mice placed on a limited diet. There was no significant difference in 


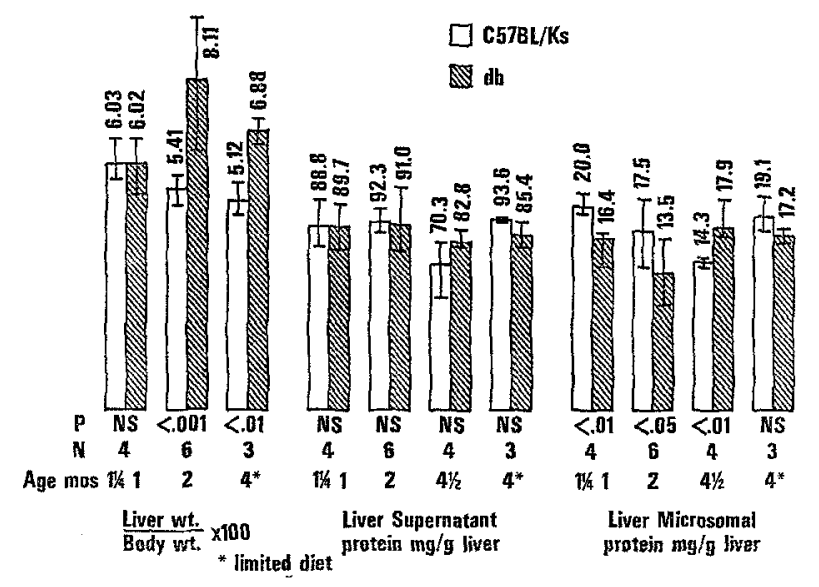

Fig. 1. Various properties of livers of diabetic $(d b)$ and control C57 BL/Ks mice. Numbers indicate the mean of results obtained from studies on $\mathrm{N}$ animals
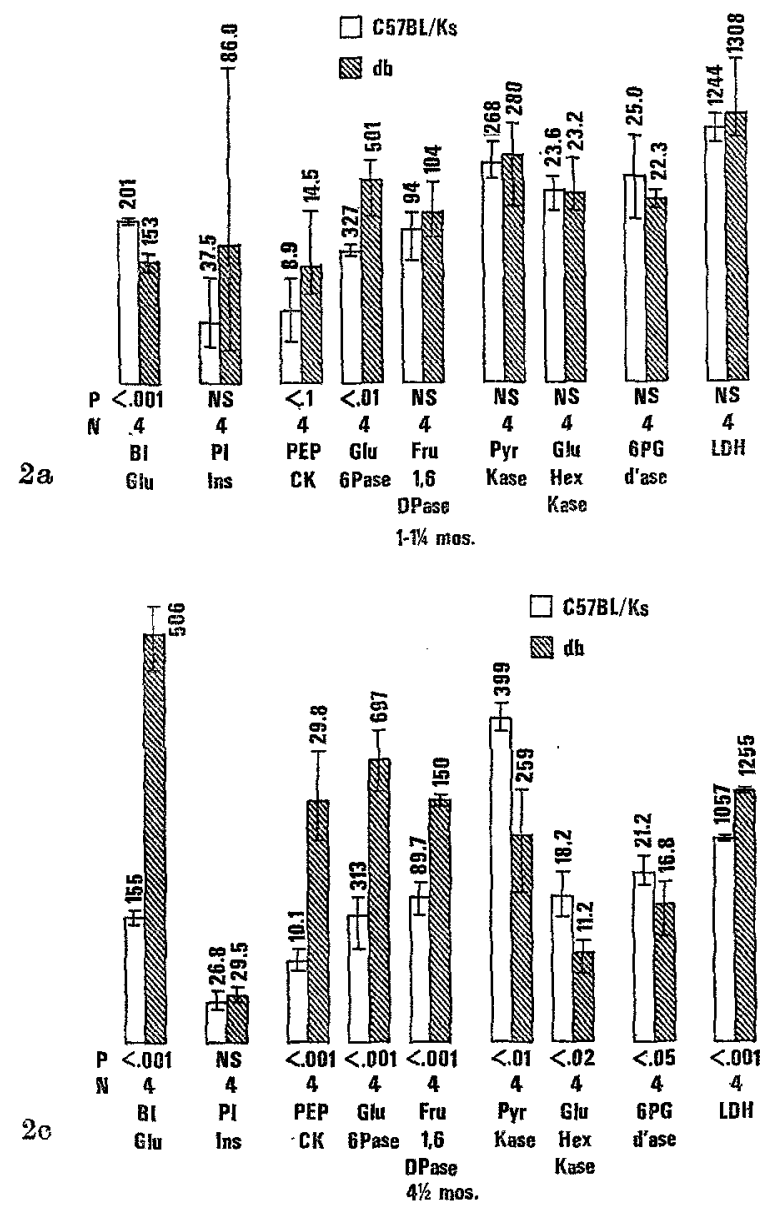

liver soluble protein content between these two groups of animals, but the microsomal protein level in the $d b$ mice appeared to change from lower ( 1 and 2 months) to higher (4 $1 / 2$ months) than that in the controls.

The $d b$ mice showed. significantly higher levels of glucose-6-phosphatase, and, probably, phosphoenolpyruvate carboxykinase, at 1 month when blood sugar concentration in these animals was normal (Fig. 2a). Hyperglycemia and hyperinsulinemia developed in the 2 month old $a b$ mice, which also had elevated phos. phoenolpyruvate carboxykinase, glucose-6-phosphatase, fructose-1,6-diphosphatase, pyruvate kinase and 6-phosphogluconate dehydrogenase activity (Fig. $2 b$ ). When these mice reached the age of $41 / 2$ months, they showed severe hyperglycemia, normal plasma insulin, depletion of insulin in pancreas [4], exorbitant amount of hepatic phosphoenolpyruvate carboxylinase, glu-
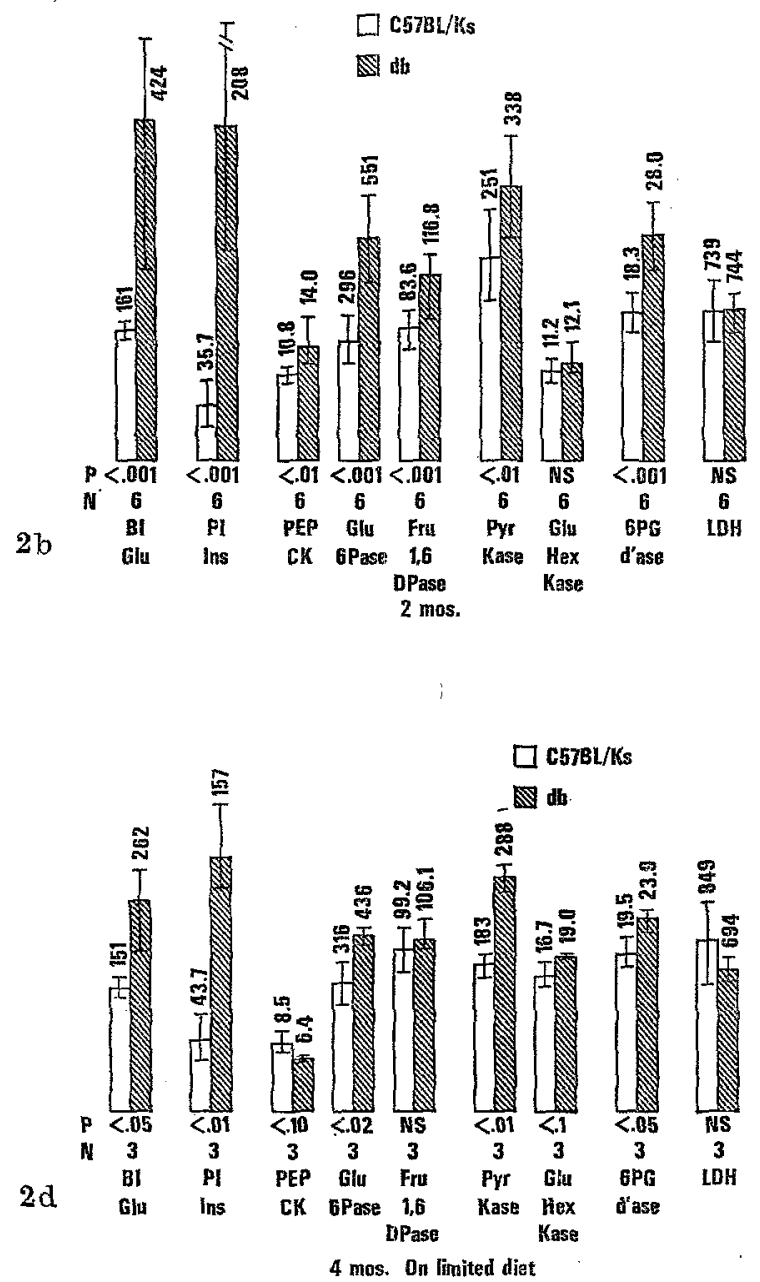

Fig. 2. Activities of hepatic enzymes of $d b$ and control mice. Numbers indicate the mean of results obtained from studies on $\mathrm{N}$ animals. Blood glucose is in $\mathrm{mg} \%$, plasma insulin $\mu \mathrm{U} / \mathrm{ml}$. Enzyme activity is defined as mum substrate turnover per minute per $\mathrm{mg}$ protein in assayed fraction. Abbreviation for enzymes is as follows: PEPCK (phosphoenolpyruvate carboxykinase), Glu6Pase (glucose-6-phosphatase), Fru 1,6 DPase (fructose-1,6-diphosphatase), PyrKase (pyruvate kinase), GluHexKase (glucose phosphorylating enzymes assayed in 0.1 IM glucose), 6PGd'ase (6-phosphogluconate dehydrogenase) and LDH (lactate dehydrogenase). Glu6Pase was assayed in microsomal fractions at $37^{\circ} \mathrm{C}$. Other enzymes were measured in the soluble fractions at $37^{\circ} \mathrm{C}$ (PEPCK, Fru 1,6DPase) or $25^{\circ} \mathrm{C}$ (GluHexKase, Pyr. Kase, 6PGd'ase and LDH) 
cose-6-phosphatase, fructose-1,6-diphosphatase and lactate dehydrogenase, and reduced quantity of pyruvate kinase, glucose-phosphorylating enzymes, and 6-phosphogluconate dehydrogenase (Fig. 2c). When young $d b$ mice were placed on a limited diet, they maintained a relatively low blood glucose level and high plasma insulin for a longer period than those fed $a d$ lib (Fig. 2 d). In addition, the disturbance in the hepatic enzyme activity was less pronounced in diabetic mice place on a limited diet.

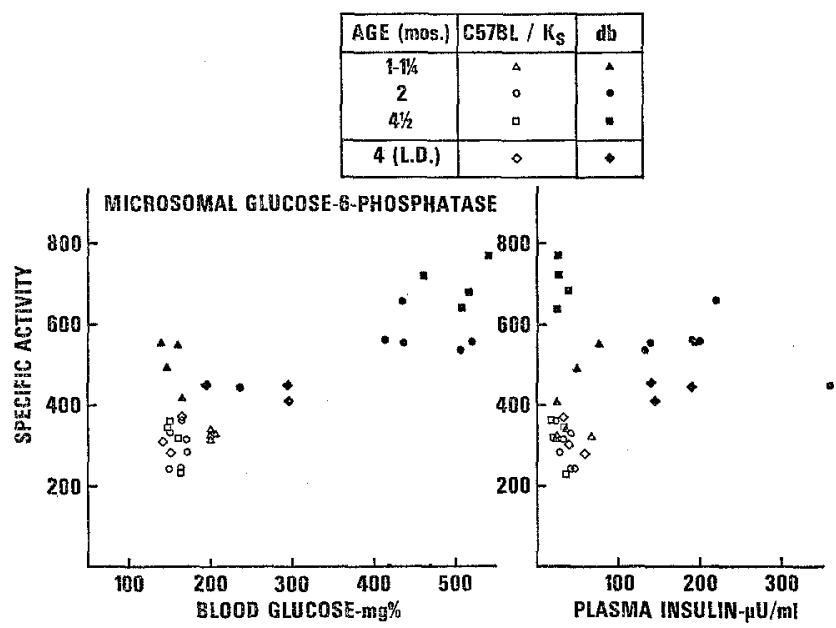

Fig. 3. Activities of glucose-6-phosphatase vs. blood glucose and plasma insulin concentrations

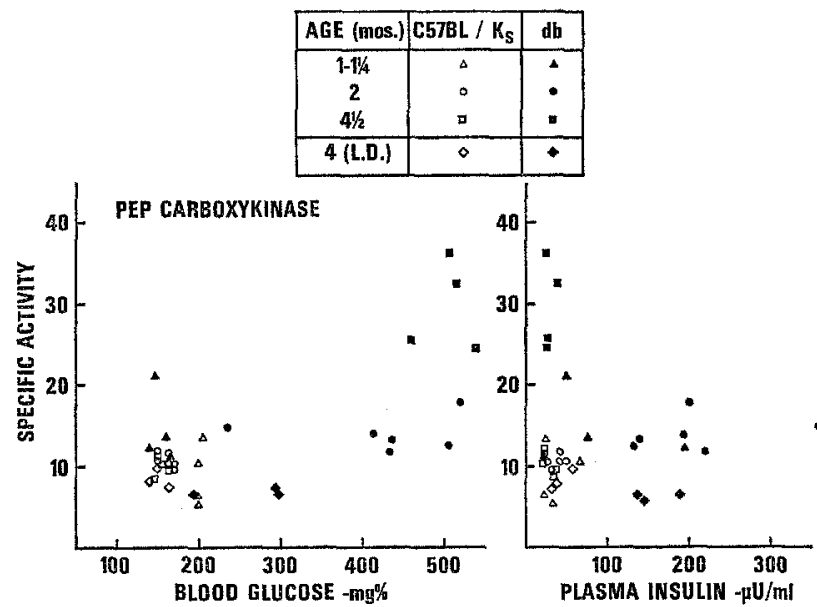

Fig. 4. Activities of phosphoenolpyruvate carboxykinase vs. blood glucose and plasma insulin concentrations

Plottings of glucose-6-phosphatase against blood glucose and plasma insulin concentrations indicate that the elevation of this enzyme preceded the onset of hyperglycemia, and could be lessened somewhat by high plasma insulin level (Fig. 3). A similar relationship was also evident in the case of phosphoenolpyruvate carboxykinase (Fig. 4).

Data obtained from studies in gluconeogenes is in vivo are summarized in Figs. 5 to 8 . Bleedings were facilitated in $d b$ mice because they were bigger and had larger blood reserve. One of the seven control mice succumbed during bleeding, and all $d b$ mice survived. The amount of blood ${ }^{14} \mathrm{C}$-glucose formed from pyruvate-2 ${ }^{14} \mathrm{C}$ was consistently higher in the $d b$ mice (Fig.

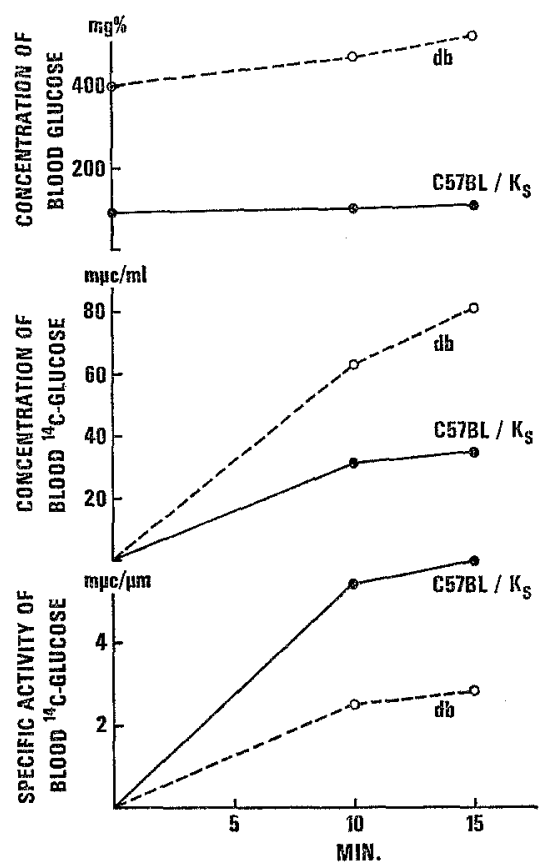

Fig. 5. Concentration and specific activity of blood ${ }^{14} \mathrm{C}$ glucose in $d b$ and control mice during gluconeogenesis studies in vivo. Each point represents the mean of studies on seven $d b$ or six control mice

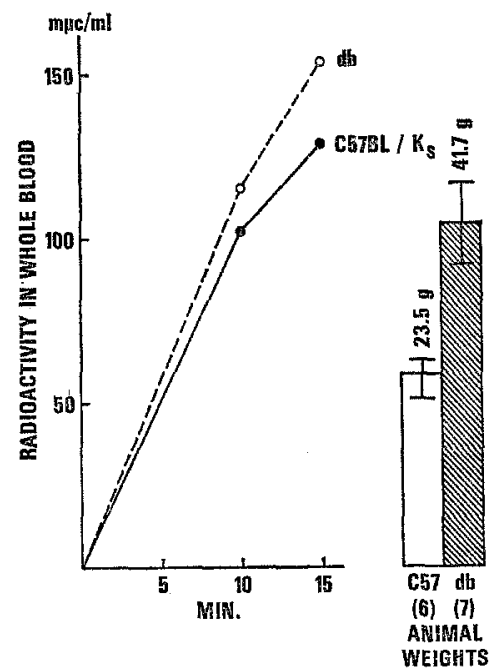

Fig. 6. Rate of absorption after I. P. injection in $d b$ and control mice. Five $\mu \mathrm{C}$ of pyruvate-2-14C was administered

5b). However, its specific activity was lower than that of control mice (Fig. 5c) due to the pre-existing large pool size of blood sugar (Fig. 5a). The amount of radioactivity appeared in unit volume of blood after 
I.P. injection seem to be similar in these two groups of animals (Fig. 6). However, because the $d b$ mice were much bigger and had more blood, the total amount of radioactivity absorbed was larger in the $d b$ mice. The rate of gluconeogenesis in vivo, based on the per cent of total radioactivity in blood found in glucose, was much higher in the diabetic mice (Fig. 7). Studies on the

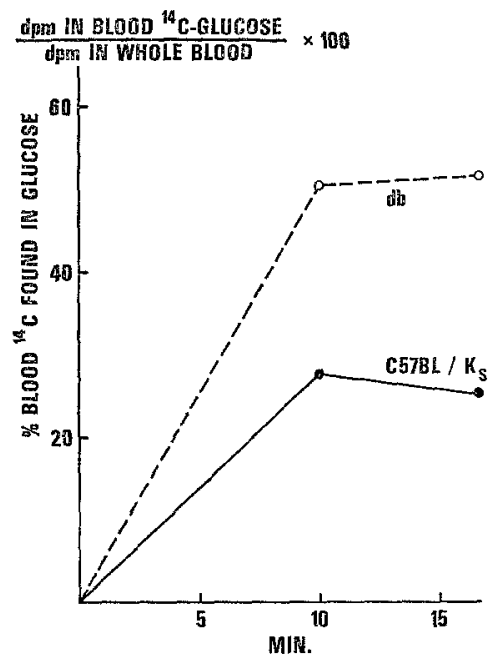

Fig. 7. Rate of ${ }^{14} \mathrm{C}$-glucose formation from sodium pyruvate $-2 \cdot{ }^{14} \mathrm{C}$

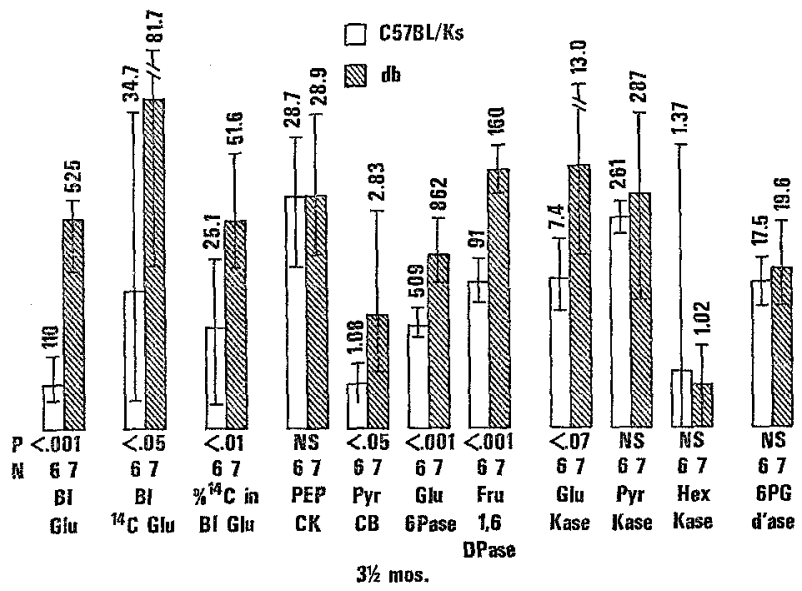

Fig. 8. Activities of hepatic enzymes in mice used in gluconeogenesis studies in vivo. The blood glucose and blood ${ }^{14} \mathrm{C}$-glucose concentrations, and $\%$ blood ${ }^{14} \mathrm{C}$ in glucose were measured in deproteinized blood cellected just before decapitation of animals. PyrCB abbreviates for pyruvate carboxylase. See legends in Fig. 2

hepatic enzymes in these animals showed significant increase in the activity of glucose-6-phosphatase, fructose-1,6-diphosphatase and pyruvate carboxylase, but not in phosphoenolpyruvate carboxykinase (Fig. 8). The $d b$ mice also had higher glucokinase activity, but similar levels in pyruvate kinase, hexokinase and 6phosphogluconate dehydrogenase as the control mice.

\section{Discussion}

Our studies showed that during the development of diabetes in the $d b$ mouse, changes in the metabolic rate of gluconeogenesis and glucose oxidation are often accompanied by alterations in activities of hepatic enzymes regulating these metabolic pathways. Thus, in the young $d b$ mouse, when the rate of glucose oxidation is accelerated [3], the level of glycolytic and pentose phosphate shunt enzymes is also elevated. Conversely, in old $d b$, retardation of glucose oxidation [3] is accompanied by depressed activity of pyruvate kinase and 6-phosphogluconate dehydrogenase. It appears that insulin may play a crucial role in regulating these changes becaues of the following observations: these enzymes are 1 . undisturbed in young $d b$ with normal plasma and pancreatic insulin level, 2. elevated in mice with high plasma insulin, and 3. depressed in mice with normal plasma insulin and depleted pancreatic insulin [4].

The regulatory role of insulin on gluconeogenic enzymes is less obvious. A higher than normal amount of these enzymes is already present in the very young $d b$ mice, before they show any sign of disturbance in blood glucose, or plasma and pancreatic insulin [4]. This suggests an early involvement of hepatic gluconeogenic enzymes in causing hyperglycemia in the $d b$ mice. At 2 months, high plasma insulin partially controls the elevation of gluconeogenic enzymes, which may reflect a net result of elevated synthesis and insulin-dependent breakdown of these enzymes in the $d b$ mice. When the mice reached the stage of insulin depletion at $4 \frac{1}{2}$ months, gluconeogenic enzymes are uncontrolled and present at an exorbitant level.

Our studies in gluconeogenesis in vivo indicate that hyperglycemia in $d b$ mice results from an accelerated rate of gluconeogenesis, in addition to a retarded state of glucose oxidation as reported by Coleman and Hummel [3]. In contrast to data observed in similar studies with diabetic chinese hamsters [2], the accelerated rate of gluconeogenesis is reflected by an increased level of gluconeogenic enzymes. Both phosphoenolpyruvate carboxykinase and glucokinase are extremely sensitive to the dietary condition and plasma insulin level as observed in studies on insulin effect in streptozotocindiabetic rats [1]. During fasting, the state of hypoinsulinemia brings on a tremendous increase in phosphoenolpyruvate carboxykinase and a decrease in glucokinase activity in the control mice. In the mature $d b$ mice, because of depletion of insulin reserve, the level of these two enzymes remains relatively unchanged between fed and fasting states. Therefore, a higher level of glucokinase in $d b$ mice but similar activity of phosphoenolpyruvate carboxykinase in both $d b$ and control mice were observed in fasting animals used in in vivo gluconeogenesis studies.

The fact that disturbance in hepatic gluconeogenic enzyme level in the $d b$ mouse precedes the onset of such symptoms as hyperglycemia, hyperinsulinemia 
and depletion of insulin in the pancreas, suggests an early involvement of liver in the development of diabetes in these animals. The manifestation of these dia. betic syndromes appears to results of excessive pro. duction of glucose which may, in turn, arise from an abnormally high quantity of hepatic gluconeogenic enzymes. However, whether liver is the primary site where mutation is manifested or a causative agent is involved in stimulating synthesis or retarding degradation of these hepatic enzymes remains to be anwered.

Acknowledgement. The authors gratefully acknowledge the supply of livers in some studies by Dr. W.E. Dulin and Mrs. B. Wyse, and their permission to use their data on blood glucose and plasma insulin in these animals.

\section{References}

1. Chang, A.Y.: Unpublished results.

2. - Schneider, D.I.: Metabolic abnormalities in the pancreatic islets and livers of the diabetic Chinese hamsters. Diabetologia. In this issue.

3. Coleman, D.L., Hummel, K.P.: Studies with the mutation, diabetes, in the mouse. Diabetologia 3, 238248 (1967).

4. Wyse, B., Dulin, W.E.: Influence of age and dietary conditions on diabetes in the $d b$ mouse. Diabetologia. In this issue,

\author{
A. Y. Chang, Ph. D. \\ Diabetes Research \\ The Upjohn Company \\ Kalamazoo, Michigan, USA
}

